the large ice sheets that are known to have existed, the low obliquity and low rate of frequency variation must occur in the same time interval. The Earth is constrained by this to remain the low-obliquity state with a prolonged cool summer season in northern high latitudes. The prolongation of the cool summer season (up to $3 \mathrm{kyr}$ ) will certainly produce large ice-age ice sheets. Again, I define an index for large glaciation as an indicator for the time of the minimum obliquity coinciding with the time interval for the minimum rate of frequency variation. The time indices for large glaciation, $I_{\mathrm{g}}$, are $-70,-192,-274$, $-396,-479,-558,-600,-642,-764,-849,-927$ and $-970 \mathrm{kyr}$. These time indices are also plotted in Fig. 3 to predict the initiation or prolongation of large glaciation.

The agreement between the indices for rapid melting and large glaciation $\left(I_{\mathrm{m}}, I_{\mathrm{g}}\right)$ found here, and the events of rapid melting and large glaciation in the geological record of climate changes as shown in Fig. 3, seems to verify the theory that the variation of the obliquity frequency is a principal forcing function for the 100-kyr ice-age cycles. Of course, the conditions for $I_{\mathrm{m}}$ and $I_{\mathrm{g}}$ are constrained by other orbital elements such as eccentricity and precession cycles. For instance, the incorrect and missing prediction of the initiation of large ice ages at $-320 \mathrm{kyr}$ and $-680 \mathrm{kyr}$ is attributable to the result of the amplitude modulation of the precession by the eccentricity ${ }^{24}$.

The importance of the 100-kyr frequency variation cycles in the excitation of the 100-kyr ice-age cycles has been examined by means of cross-correlation in the time domain. A correlation study shows that the main events of the rapid melting and prolonged glaciation in the 100-kyr ice age cycles lag behind the indices $I_{\mathrm{m}}$ and $I_{\mathrm{g}}$ in the $100-\mathrm{kyr}$ obliquity-related cycles by $\sim 2.4 \mathrm{kyr}$ and $3.8 \mathrm{kyr}$, respectively.

I have done a further series of analyses of orbital data to test the coupling effect of the time indices $\left(I_{\mathrm{m}}, I_{\mathrm{g}}\right)$ and the eccentricity. For the main melting events, the time indices $I_{\mathrm{m}}$ coincide with the maximum values of variation of the eccentricity. For the main glaciation events, however, the time indices $I_{\mathrm{g}}$ are not related to the minimum values of the eccentricity. These findings may provide a way of discriminating between the obliquityrelated $100-\mathrm{kyr}$ period and the $100-\mathrm{kyr}$ cycle in the eccentricity. According to principles of celestial mechanics ${ }^{25}$, variations in the Earth's obliquity are produced by a coupling between the motion of its orbital plane due to the gravitational perturbations of the other planets and the precession of the spin axis which results from the solar torque exerted on the Earth's equatorial bulge. Variations in the magnitude of this solar torque are determined by the instantaneous distance from the Earth to the Sun, which is governed by the eccentricity. Therefore, the frequency variation of the obliquity may be partially controlled

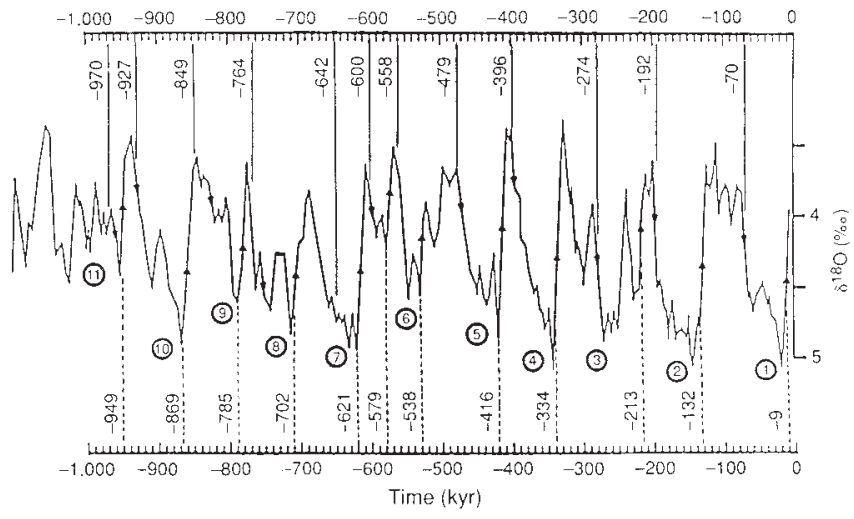

FIG. 3 Time indices for rapid melting $\left(I_{\mathrm{m}}\right)$ and large glaciation $\left(I_{\mathrm{g}}\right)$, calculated from the input obliquity signal, predict major events of rapid melting and large glaciation in the output geological record of climate changes ${ }^{23}$. (Solid lines represent $I_{g}$; dotted lines represent $I_{m}$; numbers in circles represent the sequence of glacial stages.) by the eccentricity in an intriguing way. It can be argued ${ }^{26}$ that the maximum rates of frequency variation of the obliquity can occur only when the eccentricity is high. The minimum rates of frequency variation, however, can occur regardless of the magnitude of the eccentricity. If this interpretation is correct, the $100-$ kyr cycle in eccentricity could not be the forcing mechanism for the formation of the 100-kyr glacial cycles; it can be considered only as one of the parameters that help to produce the 100 -kyr cycle in rapid melting.

Finally, the dilemma of the $100-\mathrm{kyr}$ ice-age cycle during the past million years is further complicated by the observation that before $\sim 1$ million years ago the 100 -kyr cycle in global climate was far less important. The effect of frequency variations in the obliquity on climate changes before 1 million years ago is being tested.

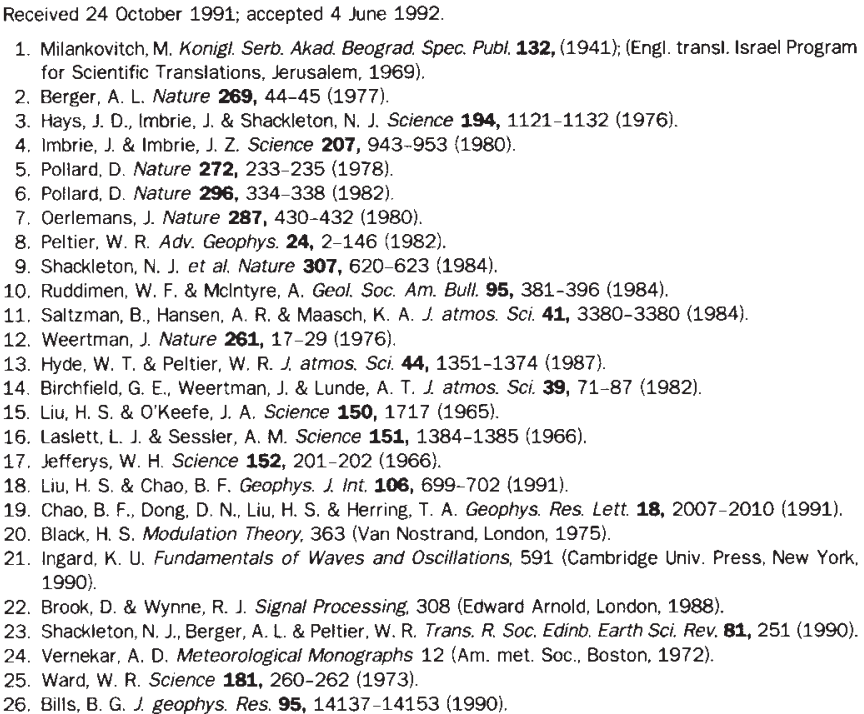

\section{Evidence for basal marine ice in the Filchner-Ronne ice shelf}

\author{
H. Oerter*, J. Kipfstuhl*, J. Determann*, H. Miller*, \\ D. Wagenbach $\dagger$, A. Minikin $\dagger$ \& W. Grafł
}

\begin{abstract}
* Alfred-Wegener-Institut für Polar- und Meeresforschung, Postfach 120161, D-W2850 Bremerhaven, Germany $\dagger$ Institut für Umweltphysik, Universität Heidelberg, Im Neuenheimer Feld 366, D-W6900 Heidelberg, Germany $\$$ GSF-Institut für Hydrologie, Ingolstaedter Landstrasse 1 , D-W8042 Neuherberg, Germany
\end{abstract}

THE Filchner-Ronne ice shelf, which drains most of the marinebased portions of the West Antarctic ice sheet, is the largest ice shelf on Earth by volume. The origin and properties of the ice that constitutes this shelf are poorly understood, because a strong reflecting interface within the ice and the diffuse nature of the ice-ocean interface make seismic and radio echo sounding data difficult to interpret ${ }^{1,2}$. Ice in the upper part of the shelf is of meteoric origin, but it has been proposed ${ }^{2-5}$ that a basal layer of saline ice accumulates from below. Here we present the results of an analysis of the physical and chemical characteristics of an ice core drilled almost to the bottom of the Ronne ice shelf. We observe a change in ice properties at about $150 \mathrm{~m}$ depth, which we ascribe to a change from meteoric ice to basal marine ice. The basal ice is very different from sea ice formed at the ocean surface, 
and we propose a formation mechanism in which ice platelets in the water column accrete to the bottom of the ice shelf.

During austral summer 1989-90 (RV Polarstern cruise ANT VIII $\left./ 5^{6}\right)$, roughly $30 \mathrm{~km}$ inland from the front of the Ronne ice shelf, Antarctica (Fig. 1), where the total ice shelf thickness is $239 \mathrm{~m}$ ( $\mathrm{N}$. Blindow, personal communication), the ice core B13 was recovered from the surface to a depth of $215 \mathrm{~m}$. We report here electrolytic conductivity measurements and oxygen isotope ratios of drill chipping samples in the liquid state. More detailed isotopic and chemical analyses as well as ice fabric studies are still under way.

The top $152.8 \mathrm{~m}$ of the core consisted of firn and bubbly ice of meteoric origin. Below this depth the ice changed at a sharp horizon to clear, bubble-free ice which contained layers of particles, and was clearly recognizable by visual inspection. The boundary corresponds to the radio-echo horizon, erroneously interpreted as the base in some earlier surveys ${ }^{1}$, but later found to be an internal reflector ${ }^{2}$. The textural, isotopic and chemical data presented here provide evidence that this basal ice layer originates from sea water. But the process of its formation is substantially different from that involved in forming sea ice at the sea surface. To distinguish the two, we introduce the term 'marine shelf ice'.

Thin sections of two core segments (Fig. 2) display the general textural patterns to be found in the marine shelf ice. Although the smallest grains and the highest diversity appear in the uppermost and oldest parts (for example, at $153.7 \mathrm{~m}$, Fig. 2a), grain sizes are several times larger in the deeper and younger layers at $190 \mathrm{~m}$ (Fig. 2b). Horizontal layering, which usually occurs in conjunction with particle inclusions and obviously prohibits crystal growth, is only found in the upper parts of the marine self ice. Preliminary microscopic analyses of the inclusions revealed mainly clastic particles, and some single diatom frustules as well as remnants of radiolarians. Although the marine shelf ice originates from sea water, its properties are distinctly different from those of sea ice. Specific sea-ice characteristics such as brine drainage channels, bubbles, pronounced $c$-axis alignments or an evenly spaced substructure ${ }^{7}$ are completely absent from our samples.

The $\delta^{18} \mathrm{O}$ values of core B13 (Fig. $3 a$ ) steadily decrease from about $-26 \%$ near the surface to $-33.5 \%$ at a depth of $\sim 135 \mathrm{~m}$. This is in good agreement with the isotope content found in surface samples at locations further south along the flow line, from where the ice found in deeper parts of the core originates.

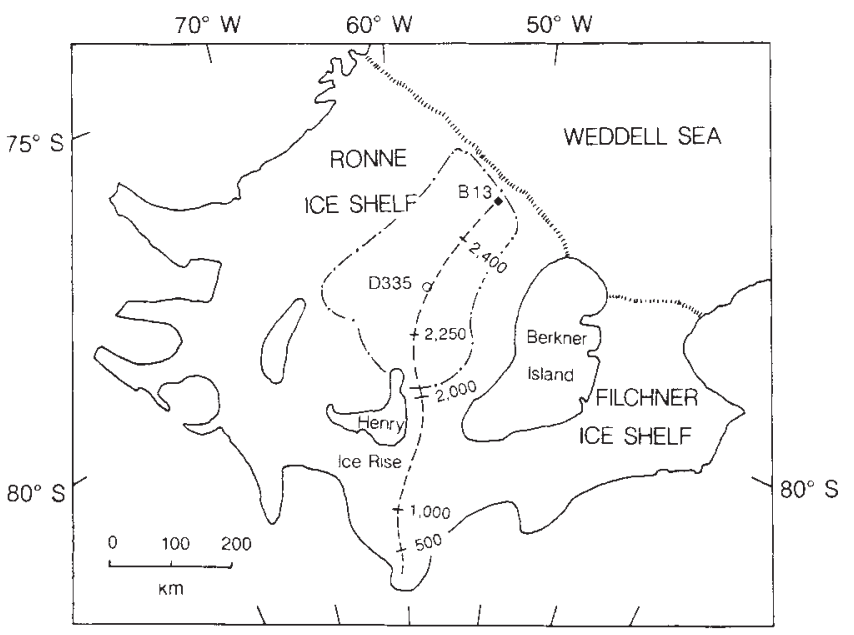

FIG. 1 Map of Filchner-Ronne ice shelf showing the location of the ice-core drill hole B13 in 1990, the hot-water drill hole at point D335 from $1986^{3}$ and an ice flow line through the location of the ice-core B13 (- - - -). Travel times of the ice shelf to the drill location are indicated. The assumed location ${ }^{2}$ of the bottom layer of marine shelf ice is also shown (- . - - - )
But the $\delta^{18} \mathrm{O}$ values decrease more rapidly between depths of $135 \mathrm{~m}$ and $152 \mathrm{~m}$, reaching a minimum value of $-40 \%$ as the transition horizon is approached. The rapid decrease suggests that this portion of the ice core was originally deposited as inland ice of higher elevation. As ice thickness at the grounding line (inland margin) exceeds $1,400 \mathrm{~m}$, a reduction to $\sim 17 \mathrm{~m}$ close to the ice front provides evidence for strong basal melting between the grounding line and the area where basal accumulation starts, at $\sim 80^{\circ} \mathrm{S}^{2,5}$. Without basal melting one would expect that the ice reaching the ice front would be $>100 \mathrm{~m}$ thick (assuming vertical thinning rates derived from an ice shelf flow model ${ }^{5}$ along a flow line through the drilling site). Thus the $\delta^{18} \mathrm{O}$ values of ice core B13 confirm basal melting beneath the deep parts of the Ronne ice shelf; this has been postulated previously from mass balance studies ${ }^{9}$ and from modelling the ocean circulation under the ice shelf $f^{9-11}$. As explained later, we believe that basal melting at the grounding line is essential for the formation of marine shelf ice.

The depth profiles of $\delta^{18} \mathrm{O}$ values and the electrolytic conductivity show very pronounced shifts at the visually recognized boundary of the two ice bodies (Fig. $3 a$ and $b$ ). Within $\sim 2 \mathrm{~cm}$, the $\delta^{18} \mathrm{O}$ values (given as the deviation from the Vienna standard mean ocean water, V-SMOW) change from -40 to $+2 \%$ and define the boundary between meteoric ice and marine shelf ice. The $\delta^{18} \mathrm{O}$ value of $+2 \%$ indicates that the marine shelf ice is frozen from sea water that has been enriched with glacial meltwater. The electrolytic conductivity of the marine shelf ice (Fig. $3 b$ ) corresponds to salinities of $<0.1 \%$. This is one order of
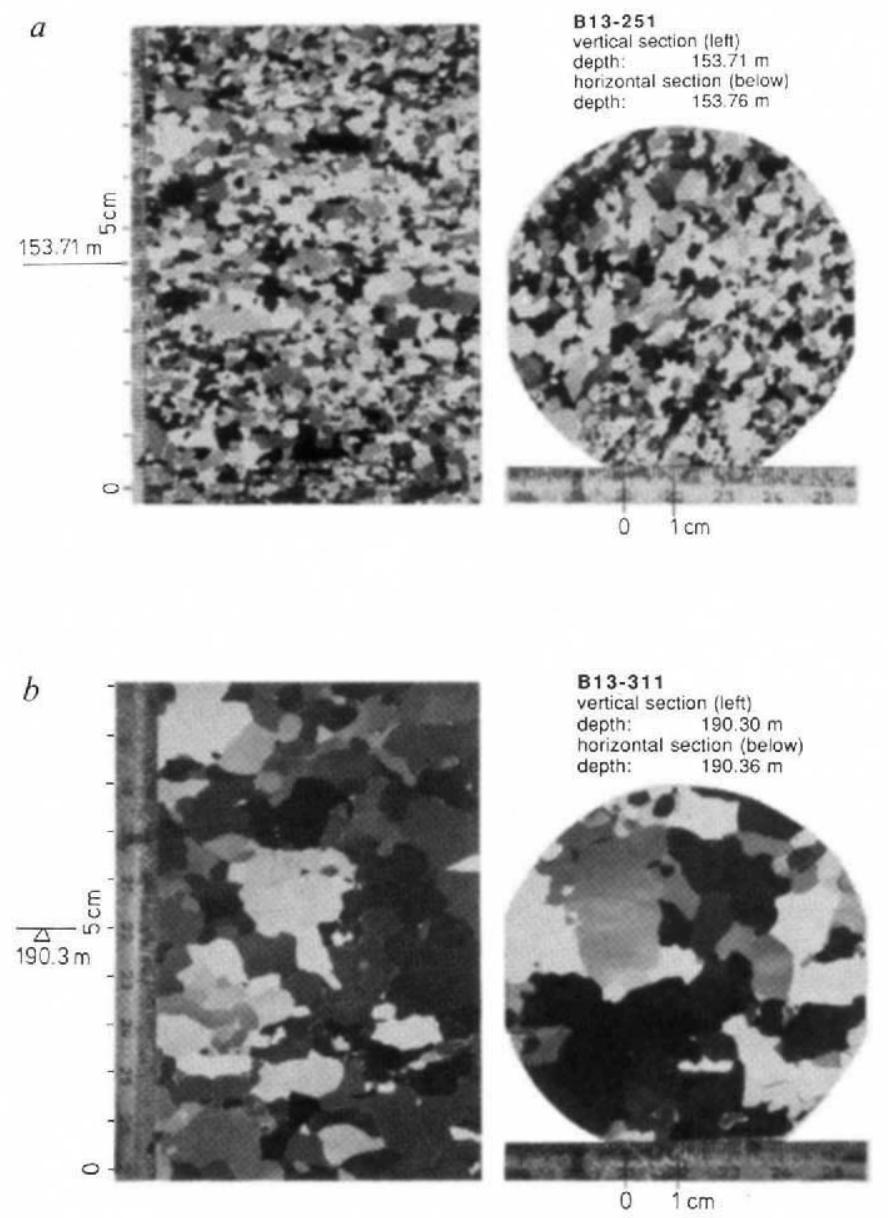

FIG. 2 Thin sections of marine shelf ice, recovered with ice-core B13 in 1990 at the central part of Ronne ice shelf from two different depths: $a$, $153.7 \mathrm{~m}$, close to the topmost layer of the marine shelf ice; $b, 190.3 \mathrm{~m}$, the bottom part of the ice core. 
magnitude above the values recorded for meteoric ice, but it is much lower than the typical salinity of sea ice $(\sim 3-10 \%$, ref. 7). The several-hundred-years-old congelation ice, frozen to the base of Ross ice shelf and recovered with the $\mathrm{J} 9$ ice core, still had salinities of $2-4 \%$ (ref. 12).

Detailed chemical analysis has been done along the entire core of the marine shelf ice on chippings, and in 1-cm depth resolution on two selected core sections. The chloride concentration decreases from 40 p.p.m. in the uppermost marine shelf ice layers to 10 p.p.m. below $180 \mathrm{~m}$ depth, which is consistent with the electrolytic conductivity record. The effective salt distribution coefficient (the ratio of the salt concentration in the ice to that of the bulk sea water) is therefore $\sim 10^{-3}$, suggesting that the build up of the marine shelf ice is driven by ice-forming mechanisms that are highly effective in rejecting common seawater ions. Accordingly, the ionic ice composition shows significant deviations from the corresponding seawater proportion: whereas $\mathrm{SO}_{4}^{2-}$ and $\mathrm{Mg}^{2+}$ are depleted with respect to $\mathrm{Cl}^{-}, \mathrm{Na}^{+}$ is enriched. This means that temperature-dependent precipitation of cryohydrates (such as mirabilite, $\mathrm{Na}_{2} \mathrm{SO}_{4} \cdot 10 \mathrm{H}_{2} \mathrm{O}$; ref. 13) which is responsible for the chemical fractionation of sea ice and sea-ice brine, is an unlikely cause of this phenomenon. Moreover, the fractionation occurring in the marine shelf ice increases with depth. The sulphate/chloride mass ratio deviates from the seawater ratio of 0.14 by $-5 \%$ in $155 \mathrm{~m}$ depth, and by $-42 \%$ in $214 \mathrm{~m}$ depth. The corresponding deviations of the sodium/chloride ratio are $+3.5 \%$ and $+14.5 \%$, and for the magnesium/chloride ratio $-10 \%$ and $-43 \%$, respectively. The decrease with depth of the electrolytic conductivity (the salinity) and the stronger chemical fractionation in the deeper layers both suggest a decrease in the formation rate for deeper (younger) parts of the marine shelf ice body.

The general pattern of both strong basal melting near the inland margin and basal accumulation in the central Ronne ice shelf can be explained by a large-scale ice pump ${ }^{14}$ working

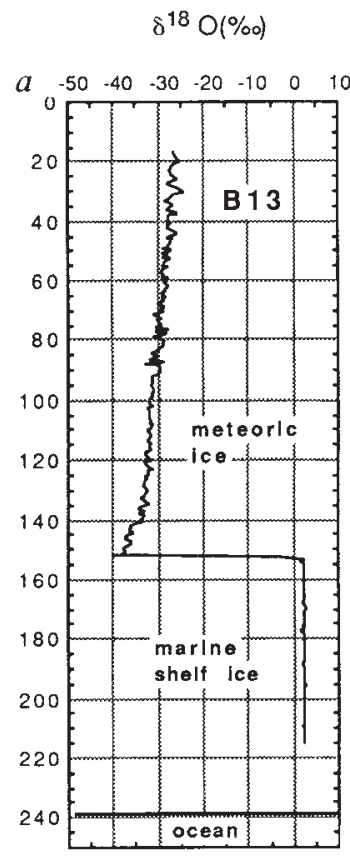

Depth $(m)$
Electrolytical conductivity $\left(\mu \mathrm{S} \mathrm{cm}^{-1}\right)$

b $\begin{array}{lllllll}0 & 40 & 80 & 120 & 160 & 200\end{array}$

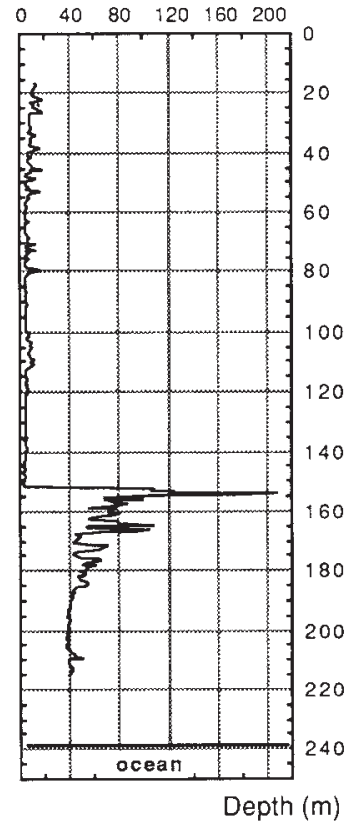

FIG. 3 Ice-core B13, Ronne ice shelf, 1990. $a, \delta^{18} 0$ profile measured at drill chipping samples. $b$. Profile of the electrolytic conductivity, measured on melted drill chipping samples. The boundary between meteoric ice and marine shelf ice is displayed with the sharp increase of $\delta^{18} \mathrm{O}$, and electrolytic conductivity. The bottom of the ice shelf was at $\sim 239 \mathrm{~m}$ ( $\mathrm{N}$. Blindow, personal communication) between the grounding line and the central part of the ice shelf (Fig. 1). This deep thermohaline convection cell in the sub-iceshelf cavity is driven by the pressure dependence of the freezing point. At the grounding line the ice-shelf draft exceeds $1,000 \mathrm{~m}$, leading to an in situ freezing point between -2.5 and $-3{ }^{\circ} \mathrm{C}$. Basal melting is caused when water masses which are above this temperature come into contact with the ice-shelf base. Being diluted by meltwater, they then become colder but buoyant and ascend along the ice-shelf base towards the north. On approaching the shallower areas north of Henry ice rise, the water becomes supercooled and tends to release ice crystals that may be similar to the ice platelets trawled offshore of the Filchner ice shelf ${ }^{15}$. The ice formation is associated with the release of latent heat and salt, leading to a warmer but denser water mass which sinks and drives a deeper counter current, transporting heat to the grounding line. Recently this hypothesis has been corroborated by profiles of temperature and salinity in the western Ronne ice shelf ${ }^{16}$.

The formation of marine shelf ice might then be explained by the following process. On their ascent through the water column the platelets scavenge suspended particles (which are found in the ice core) and initially form a slushy layer some tens of metres thick ${ }^{3,16}$. Further compaction by buoyant forces and metamorphic processes, enhanced by temperatures close to the freezing point, might then create the marine shelf ice. The observed very low salt concentration and the chemical fractionation could in principle be the result of both processes: the formation of freely floating ice crystals in the water column and their recrystallization during the evolution of the marine shelf ice. As the heat conduction of the ice shelf is very low, the formation of congelation ice is limited to a few centimetres per year ${ }^{12}$. Therefore it cannot explain the formation of the marine shelf ice.

An almost identical type of marine shelf ice found at the base of an overturned iceberg in the eastern Weddell sea ${ }^{17}$ indicates that such ice does not only exist in the Filchner-Ronne ice shelf. Moreover, the $\delta^{18} \mathrm{O}$ profile of the $\mathrm{G} 1$ ice core from the Amery ice shelf ${ }^{18}$ displays a similar pattern to the $\delta^{18} \mathrm{O}$ profile from ice core B13. In both cases a three-layered structure is found: meteoric ice deposited on the ice shelf, inland ice from the continent and marine shelf ice originating from sea water. Note that in both $\delta^{18} \mathrm{O}$ profiles, very low $\delta^{18} \mathrm{O}$ values typical for ice-age ice are absent, showing that the deepest layers of the inland ice do not survive at the ice-shelf bottom.

As inferred from an ice-shelf model ${ }^{5}, 40 \mathrm{~km}^{3}$ of marine shelf ice have to be formed each year to keep the central part of the Ronne ice shelf in a steady state. Comparing this, for example, with the $90 \mathrm{~km}^{3} \mathrm{yr}^{-1}$ of surface accumulation for the entire Filchner-Ronne ice shelf (assuming a mean precipitation rate of $0.19 \mathrm{~m}$ of ice per year ${ }^{8}$ ), demonstrates the important role of the marine shelf ice within the mass balance and dynamics of the Filchner-Ronne ice shelf.

\footnotetext{
Received 24 January: accepted 5 April 1992.

1. Robin, G de Q. et al. Nature 302, 582-586 (1983)

2. Thyssen, F. Ann. Glaciol. 11, 173-179 (1988).

3. Engelhardt. H. \& Determann J. Nature 327, 318-319 (1987)

4. Lane M A Ayeal D R / geophys. Res 91, 10457-10462 (1986).

5. Determann, J. Antarct. Sci. 3, 187-195 (1991)

6. Miller, H. \& Oerter, H. (eds) Berichte zur Polarforsch. 86 (1991).

7. Weeks, W. F. \& Ackley, S. F. U.S. Army Cold Regions Res. Eng. Lab. Monogr. $82-1$ (Hannover, 1982)

8. Graf, W., Moser, H., Derter, H., Reinwarth, O. \& Stichler, W. Ann. Glaciol. 11, 23-31 (1988).

9. Jenkins, A. J. \& Doake, C. S. M. I geophys. Res. 96, C1, $791-813$ (1991).

10. Hellmer, H. H. \& Olbers, D. J. Antarct. Sci. 1, 325-336 (1989).

11. Hellmer. H. H. \& Olbers, D. J. Antarct. Sci. 3, 433-442 (1991)

2. Zotikov, I. A., Zagorodnov, V. S. \& Raikovsky. J. V. Science 207, 1463-1465 (1980)

13. Assur, A. Nat. Acad. Sci. Nat. Res. Council. Arctic Sea lce, Publ. 598, 106-138 (Washington DC 1958)

14. Lewis, E. L. \& Perkin, R. G. J. geophys. Res. 91, 11756-11762 (1986)

15. Dieckmann, G., Rohardt, G., Hellmer, H. H. \& Kipfstuhl, J. Deep Sea Res. 33, 141-148 (1986)

16. Nicholls, K. W. Makinson, K. \& Robinson, A. V. Nature 354, 221-223 (1991)

17. Kipfstuhl, J., Dieckmann, G. Oerter, H. Hellmer. H. H. \& Graf, W. J. geophys. Res. (in the press)

18. Morgan, V. I. Nature 238, 393-394 (1972).
} 